\title{
Productivity and carbon sequestration potential of coconut-based cropping system as influenced by integrated nutrient management practices
}

\author{
V.V. Shinde*, H.P. Maheswarappa ${ }^{1}$, S.L. Ghavale, S. Sumitha ${ }^{1}$, S.M. Wankhede and \\ P.M. Haldankar \\ ICAR-AICRP on Palms, Regional Coconut Research Station, Bhatye, Ratnagiri-421 612, Maharashtra, India \\ ${ }^{1}$ ICAR-Central Plantation Crops Research Institute, Kasaragod-671 124, Kerala, India
}

(Manuscript Received: 09-03-2020, Revised:13-05-2020, Accepted: 06-07-2020)

\begin{abstract}
A field experiment was carried out at Regional Coconut Research Station, Bhatye (DBSKKV, Dapoli), Maharashtra State (India) during 2013-2018 to study the productivity and carbon sequestration potential as influenced by integrated nutrient management (INM) practices in coconut based cropping system. INM practices viz., T1- 75 per cent of Recommended Dose of Fertilizers $(\mathrm{RDF})+25$ per cent of $\mathrm{N}$ through organic recycling with vermicompost, T2- 50 per cent of RDF +50 per cent of $\mathrm{N}$ through organic recycling with vermicompost + vermiwash application + bio-fertilizer application + in situ green manuring (cowpea), T3- fully organic: 100 per cent $\mathrm{N}$ through organic recycling with vermicompost + vermiwash application + bio-fertilizer application + in situ green manuring (cowpea) and green leaf manuring + composted coir pith, husk incorporation and mulching with coconut leaves were imposed in coconut based cropping system involving nutmeg, cinnamon, banana and pineapple. For comparison, T4- control: monocrop of coconut with recommended NPK and organic manure was maintained. Four treatments were laid out in blocks of 0.11 ha area each. Among the different INM practices, treatment T1 sequestered the highest amount of above ground (coconut + nutmeg) carbon stock $\left(31.1 \mathrm{t} \mathrm{ha}^{-1}\right)$ followed by T2 $\left(30.3 \mathrm{t} \mathrm{ha}^{-1}\right)$ and T3 $\left(27.3 \mathrm{t} \mathrm{ha} \mathrm{h}^{-1}\right)$. In contrast, the treatment T4 - coconut monocrop alone had sequestered $25.6 \mathrm{t} \mathrm{ha}^{-1}$. The below-ground soil carbon stock in the rhizosphere of different crops was the highest in the nutrient management under T3 followed by T2 and T1, whereas, it was the lowest in coconut monocrop. The productivity of the system was higher in the intercropping garden. The coconut nut yield (5-year average) was higher yield under T1 (147.2 nuts palm ${ }^{-1}$ year $\left.{ }^{-1}\right)$, followed by T2 (138.4 nuts palm ${ }^{-1}$ year $\left.^{-1}\right)$ and T3 (123.6 nuts palm year $\left.^{-1}\right)$, whereas, monocrop had recorded a significantly lower number of nuts (97.2 nuts palm-1 year-1).
\end{abstract}

Keywords: Carbon sequestration, coconut, INM, intercrops, productivity

\section{Introduction}

Coconut (Cocos nucifera L.) is an important commercial plantation crop grown for its multifarious uses and cultivated in the country predominantly by smallholders in tropical regions in 2.17 million ha with a production of 21,384 million nuts and productivity of 9,815 nuts hectare ${ }^{-1}$. Kerala, Tamil Nadu, Karnataka and Andhra Pradesh are the four major coconut producing states in India, accounting for more than 91 per cent of the share in area and production (Anonymous, 2019). Monocropping of coconut is unsustainable as it utilizes only 45-50 per cent of solar radiation, 21 per cent of land area and the income derived from such a system is not sufficient to sustain even the small families (Maheswarappa et al., 2010). Furthermore, coconut growers are frequently exposed to economic risks and uncertainties owing to rapid price fluctuations. The growers of this crop were badly affected for more than two decades due to low price/price stagnation of coconut and the escalating cost of cultivation. Given this context, a coconut-based cropping system is a viable option and amenable

*Corresponding Author: vaibhavvilasshinde@yahoo.co.in 
for the integration of INM packages, which play a significant role in improving the soil properties and productivity of the system (Krishnakumar and Maheswarappa, 2010; Naveen Kumar et al., 2016 and 2017; Maheswarappa et al., 2013).

In recent past, it is a well-known fact that due to climate change, there is an increase in the concentration of carbon dioxide $\left(\mathrm{CO}_{2}\right)$ and other greenhouse gases (GHGs) leading to global warming. The key activities involved to bring down the global concentrations of GHGs are; to reduce the anthropogenic emissions of $\mathrm{CO}_{2}$ and create or promote carbon (C) sinks in the biosphere which could be achieved by promoting land-use practices such as agroforestry and intensive cropping system (Montagnini and Nair, 2004). Carbon sequestration is a mechanism for the removal of carbon from the atmosphere by storing in the biosphere (Chavan and Rasal, 2012). The coconut-based cropping systems, involving the cultivation of compatible crops especially fruit crops in the interspaces will offer considerable scope for increasing production and productivity per unit area, time and input by more efficient utilization of resources like sunlight, soil, water and labour. Besides, it will mimic a forest system and will have large scope for storage of carbon and fixing of carbon dioxide from the atmosphere, thus playing a pivotal role in sustaining the environment (Bhagya et al., 2017). Of late, humans can manage soils to accumulate carbon or avoid high losses of it with cultivation (Lal, 2010). The soil organic carbon, which traditionally has been a sustainability indicator of agricultural systems, has now acquired the supplemental role as an indicator of environmental health. Addition of soil amendments can increase the rate of plant growth and hence the amount of carbon sequestered in the soil ecosystem. There are reports that application of soil amendments can increase the growth and productivity as well as the carbon sequestered in the above-ground biomass and soil ecosystem too (Naveen Kumar et al., 2016 and 2017; Maheswarappa et al., 2013). The perennial spice crops like nutmeg, cinnamon and fruit crops viz., banana and pineapple have been found compatible and economical intercrops in wellspaced coconut gardens (Nagwekar et al., 2014). Given these facts, studies on the influence of cropping system and INM on productivity and carbon sequestration potential was carried out in coconut garden.

\section{Materials and methods}

The investigation was carried out under ICARAll India Coordinated Research Project on Palms at Regional Coconut Research Station, Bhatye (DBSKKV, Dapoli) Maharashtra, India during 2013-14 to 2018-19. The experimental station is situated at $17.00^{\circ} \mathrm{N}$ latitude, and $73.40^{\circ} \mathrm{E}$ longitude at an elevation of $3.0 \mathrm{~m}$ above mean sea level. The experimental site represents red sandy loam soil with acidic $\mathrm{pH}$ (5.8), medium organic carbon content $(0.62 \%)$ and medium-fertility status. The average annual rainfall received is $3500 \mathrm{~mm}$, of which 82 per cent is received during the monsoon months (June-September). The mean temperature ranges from $21^{\circ} \mathrm{C}$ (min.) to $36^{\circ} \mathrm{C}$ (max.), the average relative humidity varies between 60 and 95 per cent. The experiment was laid out in a 32-year-old coconut garden which was planted at a distance of $7.5 \mathrm{~m} \times 7.5 \mathrm{~m}$ in a square system. The crops in the cropping system were managed with the recommended package of practices. The experimental block of each treatment was laid out in 0.11 ha coconut garden and intercropping with released varieties of spices and fruit crops in Maharashtra State was adopted. Pictorial representation of spice and

Table 1. Fruit and spice crop species grown in coconut-based INM system

\begin{tabular}{llcr}
\hline Common name & Scientific name & Plants block $^{-1}$ & Plants ha $^{-1}$ \\
\hline Coconut var. D x T (COD x WCT) & Cocos nucifera L. & 20 & 177 \\
Nutmeg var. Konkan Swad & Myristica fragrans & 12 & 135 \\
Cinnamon var. Konkan Tej & Cinnamomum verum & 62 & 615 \\
Banana var. Safed Velchi & Musa acuminata & 62 & 615 \\
Pineapple var. Kew & Ananas comosus & 960 & 10800 \\
\hline
\end{tabular}




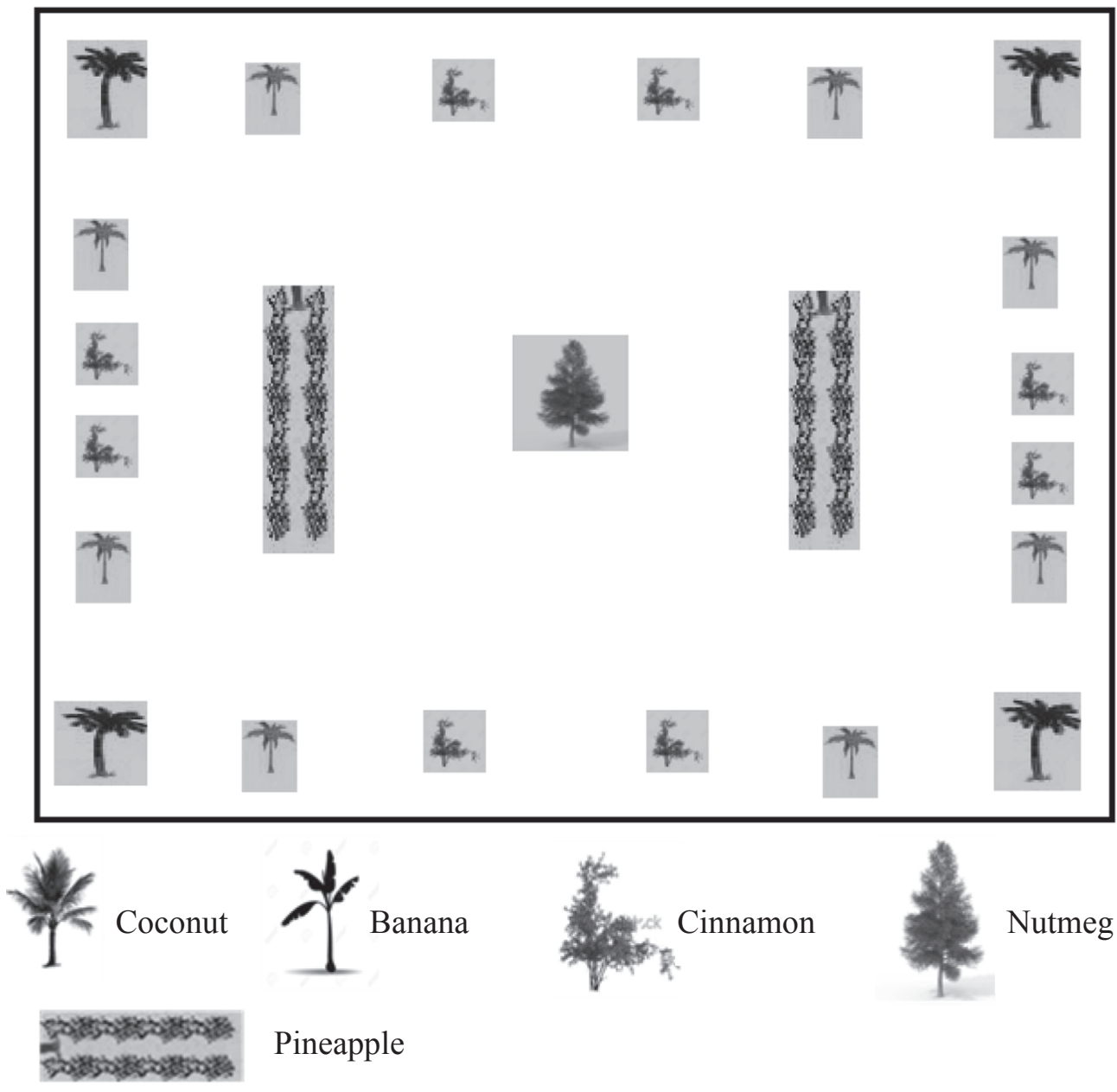

Fig. 1. Layout of single plot

fruit crops grown in the coconut garden is given in Figure 1.

\section{Integrated nutrient management (INM) practices}

T1: 75 per cent of Recommended Dose of Fertilizers (RDF) +25 per cent of $\mathrm{N}$ through organic recycling with vermicompost.

T2: 50 per cent of RDF +50 per cent of $\mathrm{N}$ through organic recycling with vermicompost + vermiwash application + bio-fertilizer application + in situ green manuring with cowpea.

T3: Fully organic: 100 per cent of $\mathrm{N}$ through organic recycling with vermicompost + vermiwash application + bio-fertilizer application + in situ green manuring with cowpea and green leaf manuring (Glyricidia leaves) + composted coir pith, husk incorporation (once in three years) and mulching with coconut leaves.

T4: Control: monocrop of coconut with recommended NPK and organic manure.

The quantity of NPK and vermicompost applied under different INM practices has been described by Maheswarappa et al. (2011). As per the different INM practices, vermicompost was applied during September-October, and inorganic fertilizers in the form of urea, single super phosphate and muriate of potash were applied in three splits doses during June-July, September-October and January-February. Vermicompost was obtained by decomposing coconut leaves and other recyclable biomass as per the procedure explained by 
Prabhu et al.(1998). The biomass was recycled back into the system after making vermicompost and recommended dose of fertilizer was applied both for coconut and component crops as per treatment details. The vermicompost was prepared and applied to meet the requirement of nutrients. The vermiwash collected was drenched in the basin of each crop by diluting it in the ratio of 1:10 with water and applied twice in the year for coconut @ 5 litres basin-1, nutmeg@3 litres tree ${ }^{-1}$, banana@2 2 litres plant ${ }^{-1}$, pineapple 4 litres in a bed of 40 plants and cinnamon (a) 2 litres plant ${ }^{-1}$. In addition to this, Glyricidia plants were grown as green manuring crop at a border of plot and green leaves were incorporated in the rhizosphere of coconut and intercrops in June, during application of fertilizer. Irrigation was provided during winter and summer months with sprinkler irrigation system based on pan evaporation data of the region at IW/CPE of 1.0. The observations on above-ground standing biomass and soil carbon stock were estimated by taking 10 trees and palms randomly in each block during December 2019. The spice crop nutmeg girth was measured at $1.3 \mathrm{~m}$ height from the base, and the total height of the species was recorded from the base of treetop by using Dendrometer.

\section{Above ground carbon sequestration in coconut}

For above-ground standing biomass estimation, the non-destructive method was adopted (Naresh et al., 2008). In coconut, the girth was measured at $1.5 \mathrm{~m}$ height from the base and height was taken up to the base of the crown.

Stem dry weight $($ SDW $)(\mathrm{kg})=$ height $(\mathrm{m}) \mathrm{x}$ girth $(\mathrm{m})^{2} \mathrm{x} 41.14142$,

Carbon stock generally, for any plant species, 50 per cent of its biomass is considered as carbon (Pearson et al., 2005).

Carbon stock $\left(\mathrm{kg} \mathrm{palm}^{-1}\right)=$ Biomass $(\mathrm{SDW}) \times$ $0.5(50 \%$ of wood biomass is considered as the carbon stored).

$$
\begin{aligned}
& \mathrm{h}=\text { height of palm }(\mathrm{m}) \\
& \mathrm{g}=\text { girth }(\text { in } \mathrm{m})=2 \pi \mathrm{r}
\end{aligned}
$$

For estimation of $\mathrm{CO}_{2}\left(\mathrm{t} \mathrm{ha}^{-1}\right)$ sequestered, multiplying carbon stock $\left(\mathrm{t} \mathrm{ha}^{-1}\right)$ with 3.67 as factor.

$$
\begin{array}{ll}
\mathrm{C}\left(\mathrm{t} \mathrm{ha}^{-1}\right) & =\mathrm{C}\left(\mathrm{kg} \mathrm{ha}^{-1}\right) \times 1000^{-1} \\
\mathrm{CO}_{2}\left(\mathrm{tha}^{-1}\right) & =\mathrm{C}\left(\mathrm{t} \mathrm{ha}^{-1}\right) \times 3.67
\end{array}
$$

Note:

$$
\begin{array}{ll}
1 \mathrm{~kg} \mathrm{CO} & =0.27 \mathrm{~kg} \text { carbon } \\
1 \mathrm{~kg} \mathrm{C} & =3.67 \mathrm{~kg} \mathrm{CO}_{2} \\
1 \text { Mega gram }(\mathrm{Mg}) & =1 \mathrm{t}
\end{array}
$$

\section{Below ground carbon stock/soil carbon stock}

For soil carbon stock estimation, soil samples were collected during December 2019 from the basin of the crops as per the standard procedures. The organic carbon content of the soil was estimated by adopting Walky-Black's method, and bulk density of the field was estimated by using core sampler at 0-30 and 31-60 cm depth described by Jackson (1967). Soil carbon stock was estimated by following the standard formula (Srinivasan et al., 2012).

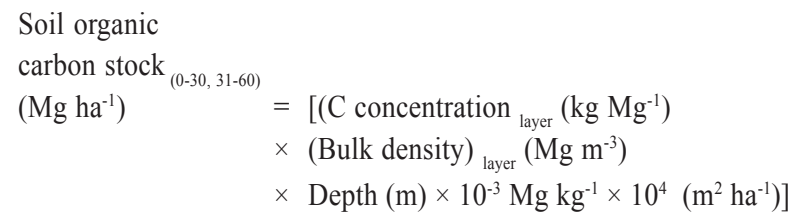

\section{Statistical analysis}

As the experiment was laid out in a block of 0.45 ha area for each treatment, the weather parameters during the year influence the productivity of the system. Hence, in the analysis, the year effect was taken as a fixed effect in the ANOVA table and treatment effect as error. The statistical analysis was performed using Statistical analysis system 9.3 computer software (SAS Institute Inc., 1995). DMRT procedure was used at $\mathrm{P}=0.05$ level to determine the significance among the treatments.

\section{Results and discussion}

\section{Yield of different intercrops}

The five-year average yield of different intercrops under coconut based cropping system with INM practices and monocrop of coconut is represented in Table 2. The data indicated that the nutmeg yield was significantly higher in T1 treatment compared to other treatments. Cinnamon 
Productivity and carbon sequestration potential of coconut influenced by INM

Table 2. Yield of coconut and different component crops (plant $\left.{ }^{-1}\right)$ under coconut based integrated nutrient management system (Pooled data 2014-15 to 2018-19)

\begin{tabular}{|c|c|c|c|c|c|c|c|}
\hline Treatment & $\begin{array}{c}\text { Coconut } \\
\text { (nuts palm-1 } \\
\text { year }^{-1} \text { ) }\end{array}$ & $\begin{array}{c}\text { Nutmeg } \\
\text { (nuts } \\
\text { tree }^{-1} \text { ) }\end{array}$ & $\begin{array}{l}\text { Nutmeg } \\
\text { mace } \\
\left(\text { g tree }^{-1}\right)\end{array}$ & $\begin{array}{c}\text { Cinnamon } \\
\text { bark } \\
\left(\mathrm{kg} \mathrm{tree}^{-1}\right)\end{array}$ & $\begin{array}{c}\text { Cinnamon } \\
\text { leaves } \\
\left(\mathrm{kg} \mathrm{tree}^{-1}\right)\end{array}$ & $\begin{array}{c}\text { Banana } \\
\left(\mathrm{kg}^{-1}\right) \\
\left.\text { plant }^{-1}\right)\end{array}$ & $\begin{array}{c}\text { Pineapple } \\
\left(\mathrm{kg}^{-1}\right. \\
\left.\text { plant }^{-1}\right)\end{array}$ \\
\hline $\mathrm{T} 1$ & 147.2 & 339.3 & 421.3 & 0.21 & 0.89 & 11.3 & 2.2 \\
\hline $\mathrm{T} 2$ & 138.4 & 312.5 & 378.1 & 0.19 & 0.73 & 10.6 & 2.0 \\
\hline $\mathrm{T} 3$ & 123.6 & 276.2 & 328.6 & 0.18 & 0.71 & 8.9 & 2.0 \\
\hline $\mathrm{T} 4$ & 97.2 & - & - & - & - & - & - \\
\hline $\mathrm{SE} \mathrm{m} \pm$ & 5.14 & 5.39 & 3.78 & 0.03 & 0.02 & 0.65 & 0.03 \\
\hline $\mathrm{CD}(\mathrm{P}=0.05)$ & 16.48 & 16.18 & 11.34 & NS & 0.07 & 1.98 & NS \\
\hline
\end{tabular}

bark yield and pineapple yield did not differ significantly among the INM treatments. The banana yield was significantly higher under T1 (11.3 $\left.\mathrm{kg} \mathrm{plant}^{-1}\right)$ and was on par with $\mathrm{T} 2\left(10.6 \mathrm{~kg} \mathrm{plant}^{-1}\right)$. With respect to coconut nut yield, T1 treatment recorded significantly higher nuts (147.2 nuts palm $^{-1}$ year $\left.^{-1}\right)$, and was at par with T2 and differed significantly with $\mathrm{T} 3$ and $\mathrm{T} 4$ treatments. The lowest yield of coconut ( 97.2 nuts palm year $^{-1}$ ) was recorded in coconut monocrop. Enhanced system productivity in coconut based cropping system with INM has been attributed to better growth of the crops, which was reflected in the yield of crops in the system. The results conform with the findings of Maheswarappa (2008), Krishnakumar and Maheswarappa (2010), Maheswarappa et al. (2013) and Naveen Kumar et al. (2016; 2017).

\section{Above ground carbon sequestration of crops}

From the data (Table 3) it was observed that, among the different INM systems, the above-ground standing biomass (SDW) and above-ground carbon stock (353.3 kg plant ${ }^{-1}$ and $31.1 \mathrm{tha}^{-1}$, respectively) was significantly the highest in the treatment $\mathrm{T} 1$ followed by T2 (345.1 kg plant ${ }^{-1}$ and $\left.30.3 \mathrm{t} \mathrm{ha}^{-1}\right)$ and T3 (310.3 kg plant $\mathrm{kg}^{-1}$ and $27.3 \mathrm{t} \mathrm{ha}^{-1}$ ),

Table 3. Influence of intercrops and integrated nutrient management practices on above ground carbon stock and sequestration under coconut garden

\begin{tabular}{|c|c|c|c|c|c|c|c|}
\hline Crop & Treatment & $\begin{array}{l}\text { Plant } \\
\text { height } \\
\text { (m) }\end{array}$ & $\begin{array}{c}\text { Plant } \\
\text { girth } \\
(\mathrm{m}) \\
\end{array}$ & $\begin{array}{c}\text { Biomass } \\
\left(\text { kg plant }^{-1}\right)\end{array}$ & $\begin{array}{c}\text { Carbon stock } \\
\left(\text { kg plant }^{-1}\right)\end{array}$ & $\begin{array}{l}\text { Carbon stock } \\
\qquad\left(\mathrm{t} \mathrm{ha}^{-1}\right)^{*}\end{array}$ & $\begin{array}{c}\mathrm{CO}_{2} \\
\text { sequestered } \\
\left(\mathrm{t} \mathrm{ha}^{-1}\right)^{*}\end{array}$ \\
\hline \multirow[t]{7}{*}{ Coconut } & $\mathrm{T} 1$ & 11.8 & 0.84 & 343.5 & 171.8 & 30.4 & 111.6 \\
\hline & $\mathrm{T} 2$ & 10.7 & 0.89 & 335.6 & 167.8 & 29.7 & 109.0 \\
\hline & $\mathrm{T} 3$ & 11.6 & 0.79 & 303.4 & 151.7 & 26.8 & 98.5 \\
\hline & $\mathrm{T} 4$ & 10.4 & 0.81 & 288.8 & 144.4 & 25.6 & 93.8 \\
\hline & Mean & 11.1 & 0.83 & 317.8 & 158.9 & 28.1 & 103.2 \\
\hline & $\mathrm{SE} \mathrm{m} \pm$ & 0.39 & 0.05 & 5.8 & 3.07 & 0.7 & 0.67 \\
\hline & $\mathrm{CD}(\mathrm{P}=0.05)$ & 1.24 & 0.17 & 18.6 & 9.82 & 2.24 & 2.14 \\
\hline \multirow[t]{6}{*}{ Nutmeg } & $\mathrm{T} 1$ & 3.04 & 0.28 & 9.7 & 4.87 & 0.66 & 2.42 \\
\hline & $\mathrm{T} 2$ & 3.18 & 0.26 & 9.5 & 4.75 & 0.64 & 2.35 \\
\hline & $\mathrm{T} 3$ & 2.53 & 0.23 & 6.9 & 3.46 & 0.47 & 1.72 \\
\hline & Mean & 2.92 & 0.26 & 8.73 & 4.36 & 0.59 & 2.16 \\
\hline & $\mathrm{SE} \mathrm{m} \pm$ & 0.16 & 0.01 & 0.35 & 0.25 & 0.02 & 0.17 \\
\hline & $\mathrm{CD}(\mathrm{P}=0.05)$ & 0.56 & 0.04 & 1.22 & 0.86 & 0.06 & 0.58 \\
\hline
\end{tabular}

Note:* indicates 177 palms ha $^{-1}$ in coconut and 135 nutmeg trees ha ${ }^{-1}$ coconut garden

SDW $=$ stem dry weight, $\mathrm{C}=$ carbon 
respectively. The lowest above-ground biomass and carbon stock was observed in coconut monocrop (288.8 kg plant ${ }^{-1}$ and 25.6 tha $^{-1}$, respectively). This is because the intercrops in coconut based cropping system have added additional biomass production than monocrop, hence the carbon stock was the highest in the cropping system plots compared to monocrop of coconut. Furthermore, the $\mathrm{CO}_{2}$ sequestered also followed the same trend and accordingly, the highest $\mathrm{CO}_{2}$ sequestration was recorded in the treatment $\mathrm{T} 1\left(114.0 \mathrm{tha}^{-1}\right)$ followed by T2 (111.4 t ha $\left.{ }^{-1}\right)$ and T3 (100.2 $\left.\mathrm{t} \mathrm{ha}^{-1}\right)$. The lowest $\mathrm{CO}_{2}$ sequestration was noticed in coconut monocrop $\left(93.8 \mathrm{tha}^{-1}\right)$. These results are in accordance with the research findings of Bhagya et al. (2017) who opined that coconut-based cropping system sequestered more carbon as compared to coconut alone. Trees are carbon reservoir on earth and in nature, forest ecosystem act as a reservoir of carbon and store a huge quantity of carbon and regulate the carbon cycle by the exchange of $\mathrm{CO}_{2}$ from the atmosphere. Thus, forest ecosystem plays a significant role in the global carbon cycle by sequestering a substantial amount of carbon dioxide from the atmosphere by storing it in the biosphere (Chavan and Rasal, 2012).

\section{Soil bulk density and organic carbon}

The data presented in Table 4 represents the bulk density of soil ( $\mathrm{g}$ per $\mathrm{cm}^{3}$ ), soil organic carbon (\%) and soil carbon stock $\left(\mathrm{t} \mathrm{ha}^{-1}\right)$ at 0-30 and 31-60 cm depth in the rhizosphere of different crops in the system. With respect to bulk density, there was no significant difference found among the different cropping system and INM practices at both the depths during this study. Whereas, the organic carbon (OC) status differed significantly among the treatments at both the depths. Among the different crops, significantly higher soil organic carbon was observed in coconut basin at $0-30$ and $31-60 \mathrm{~cm}$ depth $(0.86 \%$ and $0.81 \%)$ in the treatment $\mathrm{T} 3$ which was on par with treatment T2 and T1. The coconut

Table 4. Effect of intercrops and integrated nutrient management practices on organic carbon, soil bulk density and soil carbon stock under coconut based cropping system (2019)

\begin{tabular}{|c|c|c|c|c|c|c|c|}
\hline \multirow[t]{2}{*}{$\begin{array}{l}\text { INM } \\
\text { practices }\end{array}$} & \multirow[t]{2}{*}{ Crop } & \multicolumn{2}{|c|}{$\begin{array}{c}\text { Organic carbon } \\
(\%)\end{array}$} & \multicolumn{2}{|c|}{$\begin{array}{l}\text { Bulk density } \\
\left(\mathrm{g} \mathrm{cm}^{-3}\right)\end{array}$} & \multicolumn{2}{|c|}{$\begin{array}{c}\text { Soil carbon stock } \\
\left(\mathrm{t} \mathrm{ha}^{-1}\right)\end{array}$} \\
\hline & & $0-30 \mathrm{~cm}$ & $31-60 \mathrm{~cm}$ & $0-30 \mathrm{~cm}$ & $31-60 \mathrm{~cm}$ & $0-30 \mathrm{~cm}$ & $31-60 \mathrm{~cm}$ \\
\hline \multirow[t]{5}{*}{ T1 } & Coconut & $0.81 \mathrm{a}$ & $0.77 \mathrm{a}$ & 1.62 & 1.64 & $39.4 \mathrm{a}$ & $37.9 \mathrm{a}$ \\
\hline & Nutmeg & $0.64 \mathrm{~b}$ & $0.61 \mathrm{bc}$ & 1.60 & 1.63 & $30.7 \mathrm{~b}$ & $29.8 \mathrm{~b}$ \\
\hline & Cinnamon & $0.61 \mathrm{~cd}$ & $0.56 \mathrm{c}$ & 1.61 & 1.63 & $29.5 \mathrm{bc}$ & $27.4 \mathrm{c}$ \\
\hline & Banana & $0.63 \mathrm{~b}$ & $0.57 \mathrm{~cd}$ & 1.62 & 1.64 & $30.6 \mathrm{~b}$ & $28.0 \mathrm{~cd}$ \\
\hline & Pineapple & $0.60 \mathrm{~cd}$ & $0.54 \mathrm{~cd}$ & 1.60 & 1.62 & $28.8 \mathrm{~cd}$ & $26.2 \mathrm{~d}$ \\
\hline \multirow[t]{5}{*}{$\mathbf{T 2}$} & Coconut & $0.83 \mathrm{a}$ & $0.78 \mathrm{a}$ & 1.63 & 1.64 & $40.6 \mathrm{a}$ & $38.4 \mathrm{a}$ \\
\hline & Nutmeg & $0.66 \mathrm{~b}$ & $0.62 \mathrm{bc}$ & 1.62 & 1.63 & $32.1 \mathrm{~b}$ & $30.3 \mathrm{~b}$ \\
\hline & Cinnamon & $0.63 \mathrm{~cd}$ & $0.58 \mathrm{~d}$ & 1.62 & 1.64 & $30.6 \mathrm{bc}$ & $28.5 \mathrm{c}$ \\
\hline & Banana & $0.67 \mathrm{~b}$ & $0.61 \mathrm{~cd}$ & 1.63 & 1.64 & $32.8 \mathrm{~b}$ & $30.0 \mathrm{bc}$ \\
\hline & Pineapple & $0.62 \mathrm{~cd}$ & $0.56 \mathrm{~d}$ & 1.60 & 1.62 & $29.8 \mathrm{bc}$ & $27.2 \mathrm{~d}$ \\
\hline \multirow[t]{5}{*}{ T3 } & Coconut & $0.86 \mathrm{a}$ & $0.81 \mathrm{a}$ & 1.64 & 1.64 & $42.3 \mathrm{a}$ & $39.9 \mathrm{a}$ \\
\hline & Nutmeg & $0.67 \mathrm{~b}$ & $0.62 \mathrm{~b}$ & 1.62 & 1.63 & $32.6 \mathrm{~b}$ & $30.3 \mathrm{bc}$ \\
\hline & Cinnamon & $0.66 \mathrm{~b}$ & $0.60 \mathrm{~cd}$ & 1.62 & 1.64 & $32.1 \mathrm{~b}$ & $29.5 \mathrm{c}$ \\
\hline & Banana & $0.68 \mathrm{~b}$ & $0.63 \mathrm{~b}$ & 1.62 & 1.64 & $33.0 \mathrm{~b}$ & $31.0 \mathrm{~b}$ \\
\hline & Pineapple & $0.65 \mathrm{bc}$ & $0.60 \mathrm{~cd}$ & 1.62 & 1.64 & $31.6 \mathrm{bc}$ & $29.5 \mathrm{c}$ \\
\hline \multirow[t]{3}{*}{$\mathbf{T} 4$} & Coconut (monocrop) & $0.60 \mathrm{~cd}$ & $0.51 \mathrm{~cd}$ & 1.58 & 1.60 & $28.4 \mathrm{~cd}$ & $24.2 \mathrm{~d}$ \\
\hline & Interspace & $0.46 \mathrm{e}$ & $0.44 \mathrm{e}$ & 1.59 & 1.60 & $21.9 \mathrm{e}$ & $21.1 \mathrm{e}$ \\
\hline & $\mathrm{CD}(\mathrm{P}=0.05)$ & 0.048 & 0.79 & NS & NS & 2.1 & 3.3 \\
\hline
\end{tabular}


basin in the monocropping recorded, significantly, the lowest organic carbon at both the depths $(0.60$ and $0.51 \%)$. The rhizosphere of intercrops like nutmeg, cinnamon, pineapple and banana also recorded higher organic carbon content, whereas, in the interspace of monocropping, it was significantly lower $(0.46$ and $0.44 \%)$. Growing intercrops in the coconut garden have led to the addition of recyclable biomass from the intercrops and which has resulted in improvement in the organic carbon content. Similar results were also reported by Maheswarappa (2008) and Naveen Kumar and Maheswarappa (2019) in coconut based cropping system with INM.

\section{Soil carbon stock}

The soil carbon stock was significantly influenced by the coconut-based cropping system and INM practices (Table 4). Among the different crops under investigation, the coconut rhizosphere in the treatment T3 had significantly higher soil carbon stock $\left(42.3 \mathrm{tha}^{-1}\right.$ and $\left.39.9 \mathrm{tha}^{-1}\right)$ in the depths of $0-30$ and $31-60 \mathrm{~cm}$ followed by treatment $\mathrm{T} 2$ (40.6 $\mathrm{t} \mathrm{ha}^{-1}$ and $38.4 \mathrm{tha}^{-1}$ ) and $\mathrm{T} 1$ (39.4 $\mathrm{t} \mathrm{ha}^{-1}$ and $\left.37.9 \mathrm{tha}^{-1}\right)$. The lowest soil carbon stock of $28.4 \mathrm{tha}^{-1}$ and $24.2 \mathrm{t} \mathrm{ha}^{-1}$ at $0-30$ and $30-60 \mathrm{~cm}$ depth was noticed in the coconut rhizosphere in monocrop (T4). Among the different INM practices in coconut based cropping system, significantly higher soil carbon stock was observed in the treatment $\mathrm{T} 3$ at 0-30 and 31-60 cm depth in the rhizosphere of different crops followed by $\mathrm{T} 2$ and $\mathrm{T} 1$. The lowest soil carbon stock in the coconut monocrop (T4) might be due to the absence of intercrops in the interspace, which might not have contributed to the soil carbon pool. Furthermore, the coconut basin rhizosphere has recorded higher carbon stock at both depths (0-30 and 31-60 cm), which might be due to increase in organic carbon in the soil owing to decomposition of root system over a period of time as compared to other crops and organic manure incorporation to the coconut crop and interaction effect of organic manure and green manure incorporation. Similar findings were observed in orchard wherein, the beneficial effects of sustainable practices (residue incorporation, cover crop retention and compost application) on yield which was improved as compared with conventionally managed orchards (Xiloyannis et al., 2014;
Bhagya et al., 2017; Naveen Kumar and Maheswarappa, 2019).

\section{Conclusion}

The present study on coconut-based cropping system with different intercrops under INM practices in the coastal ecosystem of Maharashtra has substantially contributed towards improving the above and below ground carbon stock of the system. The above-ground standing biomass and carbon stock recorded was the highest in T1, followed by $\mathrm{T} 2$ and T3, and the lowest was in coconut monocrop. In respect of soil carbon stock, among the different crops under investigation, the coconut rhizosphere in the treatment T3 had significantly higher soil carbon stock followed by treatment $\mathrm{T} 2$ and $\mathrm{T} 1$. In contrast, the lowest sequestration of soil carbon stock was noticed in coconut monocrop. The productivity of the system was higher in the intercropping garden with INM practices, whereas monocrop had recorded significantly lower productivity. Thus by intercropping with spice and fruit crops in coconut garden along with INM practices, the carbon stock is higher along with an increase in the system productivity over a period of time as compared to the monocropping system of coconut.

\section{Acknowledgements}

The authors are thankful to the ICAR-AICRP on Palms, ICAR-Central Plantation Crops Research Institute, Kasaragod, Kerala and Director of Research, DBSKKV, Dapoli for providing the facilities.

\section{References}

Anonymous, 2019. Horticulture Division, Department of Agriculture and Cooperation, Ministry of Agriculture and Farmers Welfare, Government of India, Database 201819.

Bhagya, H.P., Maheswarappa, H.P., Surekha and Bhat, R. 2017. Carbon sequestration potential in coconut based cropping systems. Indian Journal of Horticulture 74(1): $1-5$.

Chavan, B. and Rasal, G. 2012. Total sequestered carbon stock of Mangifera indica. Journal of Environment and Earth Science 2: 37-48.

Jackson, M.L. 1967. Soil Chemical Analysis, Prentice Hall of India, Pvt. Ltd., New Delhi, 498 p. 
Krishnakumar, V. and Maheswarappa, H.P. 2010. Integrated nutrient management for root (wilt) diseased coconut (Cocos nucifera L.) palms. Indian Journal of Agricultural Sciences 80(5): 394-398.

Lal, R. 2010. Enhancing eco-efficiency in Agro ecosystems through soil carbon sequestration. Crop Science 50: 120-131, doi: 10.2135/cropsci_2010.01.0012.

Maheswarappa, H. P. 2008. In situ waste management in integrated nutrient management system under coconut (Cocos nucifera) -based high density multi-species cropping system in tropical soils of India. Indian Journal of Agricultural Sciences 78(11): 924-8.

Maheswarappa, H.P., Palaniswami, C., Dhanapal, R. and Subramanian, P. 2010. Coconut based intercropping and mixed cropping systems. In: Coconut Based Cropping/ Farming Systems, (Eds.) Thomas, G.V., Krishnakumar, V., Maheswarappa, H.P. and Palaniswami, C. CPCRI, Kasaragod, pp. 9-31.

Maheswarappa, H.P., Thomas G.V., Bhat, R., Palaniswami, C. and Jayasekhar, S. 2011. Impact of inorganic fertilizer substitutions by vermicomposted coconut leaves on productivity and economics of coconut. Journal of Plantation Crops 39(1): 30-34.

Maheswarappa, H.P., Dhanapal, R., Subramanian, P. and Palaniswami, C. 2013. Evaluation of coconut based high density multi-species cropping system under organic and integrated nutrient management. Journal of Plantation Crops 41(2): 130-135.

Montagnini, F. and Nair, P.K.R. 2004. Carbon sequestration: An under exploited environmental benefits of agro forestry system. Agro Forestry System 61-62: 281-288.

Nagwekar, D.D., Haldankar P. M., Arulraj, S., Jadhav, B.B. and Maheswarappa, H.P. 2014. Lakhi Baug for realizing maximum income from coconut. Indian Coconut Journal 57(6): 23-26.
Naresh, K.S., Kasthuri, B.K.V. and George, J. 2008. A method for non-destructive estimation of dry weight of coconut stem. Journal of Plantation Crops 36: 296-99.

Naveen kumar, K. S., Maheswarappa, H. P. and Basavaraju, T. B. 2016. Effect of integrated nutrient management practices on growth and yield of vegetable crops grown as intercrops in coconut garden. Indian Journal of Agricultural Sciences 86(10): 1361-5.

Naveen Kumar, K.S., Maheswarappa, H.P. and Basavaraju, T.B. 2017. Productivity and economic benefits of coconut based vegetable cropping systems under central dry zone of Karnataka. Journal of Plantation Crops 45(1): 49-56.

Naveen Kumar, K.S. and Maheswarappa, H. P. 2019. Carbon sequestration potential of coconut based cropping systems under integrated nutrient management practices. Journal of Plantation Crops 47(2): 107-114.

Pearson, T.R.H., Brown, S. and Ravindranath, N.H. 2005. Integrating carbon benefits estimates into GEF Projects: $56 \mathrm{p}$.

Prabhu, S.R., Subramanian, P., Biddappa, C.C. and Bopaiah, B.M. 1998. Prospects of improving coconut productivity through vermiculture technology. Indian Coconut Journal 29(4): 79-94.

SAS Institute. 1995. SAS/STAT guide for personal computer version 6. SAS Institute, Cary, NC.

Srinivasan, V., Maheswarappa, H.P. and Lal, R. 2012. Long term effects of topsoil depth and amendments on particulate and non-particulate carbon fractions in a Miamian soil of Central Ohio. Soil and Tillage Research 121: $10-17$.

Xiloyannis, C., Montanaro, G., Mininni, A.N. and Dichio, B. 2014. Carbons capture and soil biological activity in fruit tree orchards. European Conf. on Green Carbon: Making Sustainable Agriculture Real Brussels, April 1-3, 2014, pp. 20. 